\title{
Dimensions of Textile, Clothing and Footwear Production in the High Wage Cost Country of Australia in a Globalised Environment: Some Interesting Revelations
}

\author{
Andrew Marks ${ }^{1}$ \\ ${ }^{1}$ School of Business, University of Western Sydney, Sydney, Australia \\ Correspondence: Andrew Marks, School of Business, University of Western Sydney, Sydney, Locked Bag 1797, \\ 1797, Penrith, NSW, 2751, Australia. Tel: 61-4-620-3030. E-mail: a.marks@uws.edu.au
}

Received: May 15, 2015

doi:10.5430/rwe.v6n2p72
Accepted: June 14, 2015

Online Published: June 18, 2015

URL: http://dx.doi.org/10.5430/rwe.v6n2p72

\begin{abstract}
This paper seeks to assess the performance of the labour intensive and high wage cost textile, clothing and footwear (TCF) industry in Australia in a globalised environment. The results indicate the Australian TCF industry has become a leaner and more specialised export focused industry by restructuring production from the low to high value added products which exhibit a comparative advantage on the international market. A particularly interesting dimension has been the greater use of high tech production techniques such as bolstering net investment expenditure which has increased the capital intensity of production, undertaking elevated levels of R\&D expenditure and using a more skilled labour force which have combined to made it possible to use computer controlled technology and microelectronics to facilitate the production of the higher value added TCF products. This has also combated costs of production and improved the quality of these products thereby reinforcing export competitiveness. The sharper export focus importantly, has provided a platform for sustainable output and employment growth, albeit on a smaller scale. However, this has been associated with large output and hence employment losses.
\end{abstract}

Keywords: Australia, textile, clothing, footwear, specialisation, high tech, wages, exports

\section{Introduction}

A major challenge confronting small, open and high wage cost economies such as Australia is how to sustain labour intensive manufacturing industries in a globalised environment where strong competition emanates from countries with a larger population and hence a lower wage cost structure and which also experience technological change. Such is the case with the Australian textile, clothing and footwear (TCF) industry with the authorities seeking to respond to this challenge by improving its international competitiveness and hence export focus. The extent to which the Australian TCF industry has integrated onto the much large international market therefore will constitute the central thrust of this paper due to the critical implications for sustainable output and employment growth of an important $\operatorname{cog}$ of the manufacturing sector This objective will be pursued by assessing the impact of the major policy initiatives in the form of trade liberalisation and reinforcing industry specific assistance measures on a number of indicators which constitute this industry's economic fundamentals such as labour productivity, investment and research and development expenditure and changes in the quality of output. This will make it possible to ultimately gauge the impact of policy on the export profile of the TCF industry. Emphasis will also be given to any employment losses arising from the efforts of a labour intensive industry to restructure its operations in order to survive in a globalised environment where strong competition prevails. The results of this study will provide an insight into the response of a labour intensive industry in a high wage cost country in the context of a globalised environment which in the process will complement the existing studies on the Australian and hence international TCF industry.

The rest of the paper is organised as follows. Section 2 consists of an overview of the previous studies on the Australian TCF industry with the following section canvassing the theory of trade liberalisation.in order to assess the expected impact on labour intensive high wage cost TCF production. Section 4 highlights the impact of policy on international competitiveness by examining changes in a number of economic indicators which include labour productivity, investment expenditure, $R \& D$ expenditure and changes in the quality of output. This in turn makes it possible to evaluate the extent to which higher export oriented production has been achieved, a task pursued in section 5 . The following section will attempt to disclose some of the relatively more important costs associated with 
any improvement in export based production with particular emphasis on employment. Section 7 will assess the impact of changes in employment on wages due to the implications for international competitiveness. The final section provides a conclusion and a brief analysis of the policy implications of the major findings of the paper.

\section{Previous Studies}

Numerous studies have been undertaken on the Australian TCF industry. For example, (Jayanthakumaran 2001) assesses the impact of trade liberalisation on the economic performance of the TCF industry (at the four digit level) and small to medium sized enterprises (SMEs) within this industry using a cross sectional regression model in the period 1992/93-1996/97. Some of the relatively more important results include the stimulus provided by greater openness on labour productivity (measured as output per employee) and export growth. It is also revealed that trade liberalisation has led to higher price mark ups which indicate stronger import competition has not alleviated the abuse of market power. Furthermore, trade liberalisation has exacerbated the trade deficit in TCF goods. In relation to SMEs, greater openness has had a positive impact on labour productivity growth but a negative effect on export growth (although SMEs with employees between 5-10 and 10-20 increased exports).

In another study, (Webber and Weller 2001) evaluate the impact of the trade liberalisation induced restructuring of the TCF industry on employment based on the level of skill and gender for the purpose of evaluating changes in the distribution of income. Some of the relatively more interesting revelations include employment losses in the low skill areas such as labourers and related workers as a result of the contraction of production, and employment growth in the higher skill areas such as managers and professionals due to the expansion of wholesale and retail trade. These two developments ultimately combined to lead to the deterioration in the distribution of income within the workers of this industry. Another interesting find has been the growth in higher skill jobs favouring women and the loss of the low skill jobs been concentrated among men thereby leading to an improvement in the distribution of income for women and the deterioration for men.

Furthermore, (Weller and Webber 1999) undertake a study to disclose the important influences on the employment prospects of retrenched workers (both males and females) in the labour intensive Australian TCF industry in the period 1993-1997, using logistic regression analysis within the framework of a discrete-time event history model. These influences include labour market conditions, household characteristics, skill of retrenched workers, TCF job held, personal characteristics, post retrenchment experience and training participation. Whilst all these influences exerted a statistically significant impact on the employment prospects of retrenched TCF workers, with the exception of TCF job held, household characteristics for males and labour market conditions for females were the most important factors affecting their employment prospects. Training participation constituted the second most important factor for both males and females.

Other studies undertaken on the Australian TCF industry include the (Industry Assistance Commission (IAC) 1986), (Industry Commission (IC) 1997) and (Productivity Commission (PC) 2003). Two other studies incorporate the Australian TCF industry as part of their studies. The first is by Marks (2013) which uses the Australian and TCF industries of other western market economies as a proxy for labour intensive manufacturing production to highlight the uncompetitive nature and hence contraction of labour intensive production in a globalised environment. In contrast, western market economies dominate capital intensive production as reflected by their dominance of the global motor vehicle industry. It is emphasised these trends ultimately lead to these economies experiencing an outflow of resources from labour intensive manufacturing industries and the inflow of resources into capital intensive industries. The other study by Marks (2009) uses the Australian TCF and motor vehicle industries to gauge the intra industry trade response and hence adjustment costs of two industries characterised by different factor intensive in production i.e. the TCF industry is labour intensive and the motor vehicle capital intensive. The results reveal the labour intensive TCF industry has exhibited a weaker intra industry trade response and hence higher adjustment costs relative to the motor vehicle industry. The current study seeks to complement the existing literature on TCF production by providing an insight into the response of the labour intensive TCF industry in a high wage cost country such as Australia in a globalised environment.

\section{Theory of Free Trade}

International trade theory highlights the move towards free trade will intensify import competition thereby prompting the re-allocation of resources from the areas of least to those with the greatest comparative advantage thereby raising productivity growth and hence improving export competitiveness. A similar response to trade liberalisation can be expected from industries, like the labour intensive TCF industry in relatively high wage countries such as Australia. Specifically, the stronger import competition is expected to prompt the restructuring of TCF production from the labour intensive, low productivity and low value added products which are least competitive on the international 
market to the more capital intensive higher productivity and higher value added products which exhibit a comparative advantage thereby sharpening the export focus of this industry. It needs to be emphasised that implementing trade liberalisation to promote improvements in international competitiveness and hence export oriented production will not only occur via restructuring induced productivity gains and higher value added production but also through other avenues. They include the impetus provided by stronger import competition for higher investment expenditure, additional research and development (R\&D) expenditure, improvements in the quality of the goods produced and education and training reforms to raise the skill level of the labour force, amongst other avenues.

\section{The Impact of Policy on International Competitiveness}

It has been emphasised in the introduction that the fundamental purpose of the policy in the form of trade liberalisation and the reinforcing industry specific assistance measures has been to improve the international competitiveness of the TCF industry in order to reorient production towards the international market. This objective is ultimately achieved if the economic fundamentals improve. The major focus of this section therefore will be to scrutinise a number of economic indicators which constitute the TCF industry's economic fundamentals such as labour productivity growth, investment expenditure, $R \& D$ expenditure and changes in the quality of output. The analysis will begin from 1987/88 because of the assertion by (Corden 1996) that the real beginning of the trade liberalisation process for all segments of the manufacturing sector began in 1988 under the (May Economic Statement 1988) which had formulated a plan of future reductions in import protection levels for the first time. This in turn reinforced the commitment of government towards the program of trade liberalisation for the TCF industry which had begun in the early1980s.

\subsection{Labour Productivity}

The impact of the policy environment on labour productivity in the period 1988/89-2012/13 is displayed by the following figure. (Note 1)

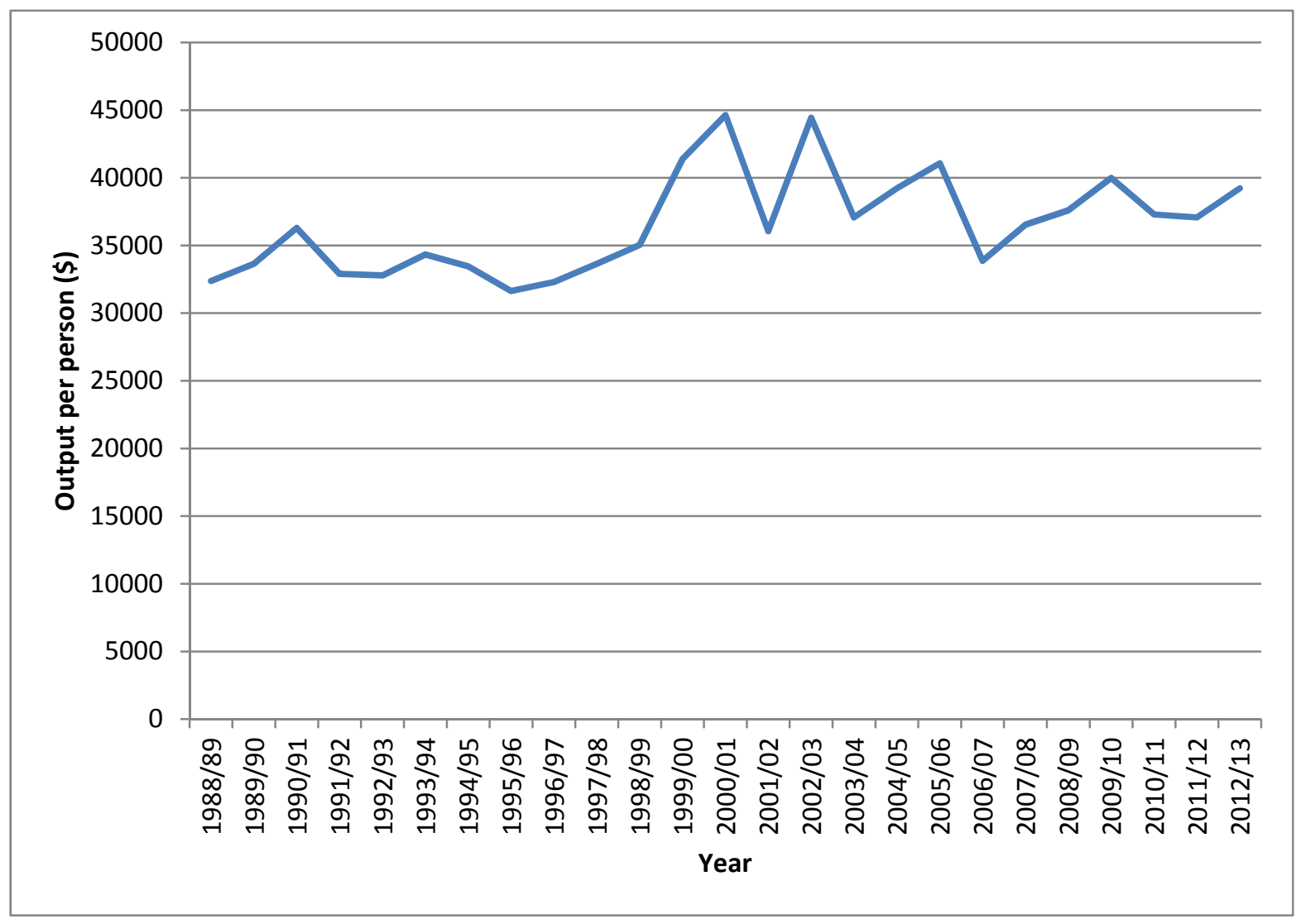

Figure 1. Labour productivity 
The first interesting dimension of Figure 1 is the tendency for labour productivity to rise. The major driver of this trend appears to be the powerful incentive provided by the progressive reductions in import protection levels to confront this challenge by improving international competitiveness. This assertion is consistent with the studies of (Jayanthakumaran 2001) and the (IC 1997) which reveal the critical importance of the move towards free trade in stimulating labour productivity growth in earlier phases of the trade liberalisation process. (Note 2) The cornerstone of this response has been the restructuring of production from the activities with the least to those with the greatest comparative advantage on the international market. Specifically, production has shifted from the labour intensive low value added to more capital intensive high value added TCF products which exhibit stronger export penetration i.e. see (IC 1997) for these effects in the earlier phase of the trade liberalisation period.

This implies rising capital intensity of TCF production is likely to have been fundamentally the product of the restructuring process. Nevertheless, the drive by firms to replace labour in a labour intensive industry with capital in order to exert a powerful downward jolt to costs of production and hence reinforce improvements in international competitiveness is also likely to have been important. The more capital intensive nature of TCF production in the period 1988/89-2012/13 is highlighted by the following figure. (Note 3)

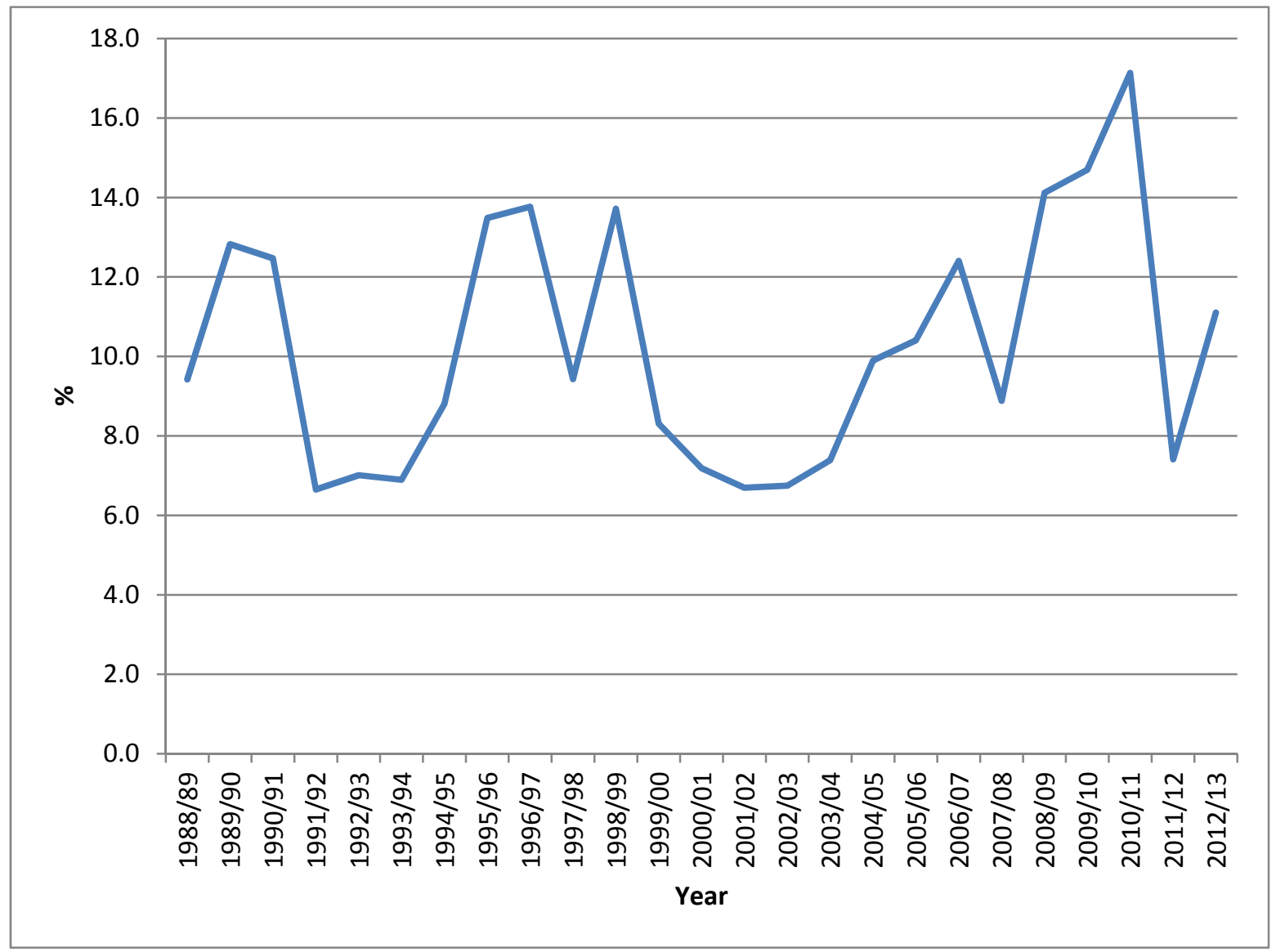

Figure 2. Capital intensity of production

Figure 2 depicts an upward trend in the capital intensity of TCF production. This trend is likely to have been given imputes by the generous incentives for investment expenditure under the IDS and larger in magnitude SIP programmes. Indeed, the (IC 1997) reveals the positive impact of the IDS on investment expenditure whilst the (PC 2003) highlights a similar impact of the SIP. It is noteworthy to mention that more capital intensive production facilitates the use of computer controlled technology and microelectronics which reinforces labour productivity growth by speeding up the production process and combats labour costs by shedding labour, features which accompany a more mechanised and hence automated production process. For example, computer controlled cutting 
can reduce the time taken to cut a suit from one hour to four minutes. Similar production techniques have also been evident in the TCF industries of other western market economies i.e. see Dicken (2011). Finally, it is also important to mention the limited increase in the capital intensity of production which highlights the inherent difficulty of a labour intensive industry to use capital to increase output and hence productivity. Another interesting feature of Figure 1 is the stagnation in labour productivity growth in more recent years which appears to constitute a natural phenomenon as it becomes progressively more difficult to sustain increases over time from the same major driver i.e. trade liberalisation. Finally, the trend growth in labour productivity conceals the limited average annual increase of 0.8 of one percent which in turn indicates the inherent difficulty of labour intensive industry to boost its economic efficiency.

A contribution to the higher labour productivity is also likely to have emanated from the economy wide microeconomic reforms. For example, education and training reforms have increased the skill level of the labour force in the TCF industry thereby enhancing its productive power i.e. see (IC 1997). A particularly important dimension has been the cultural change by firms in favour of continued education and training to constantly upgrade the skills of the labour force. Furthermore, the introduction of enterprise bargaining (in 1987) which linked improvements in wages and working conditions to productivity offsets is also likely to have made a contribution. Indeed, this has led to the appearance of improved workplace efficiency as reflected in greater flexibility in skills usage (multi-skilling) and work time (shift work and overtime arrangements) thereby also boosting labour productivity i.e. see (IC 1997).

\subsection{Investment Expenditure}

It is also interesting to evaluate the response of investment expenditure to the policy of globalising TCF production in Australia. This is pursued by scrutinising the behaviour of (real) net capital investment expenditure in the period 1988/89-2012/13 which is depicted by the following diagram.

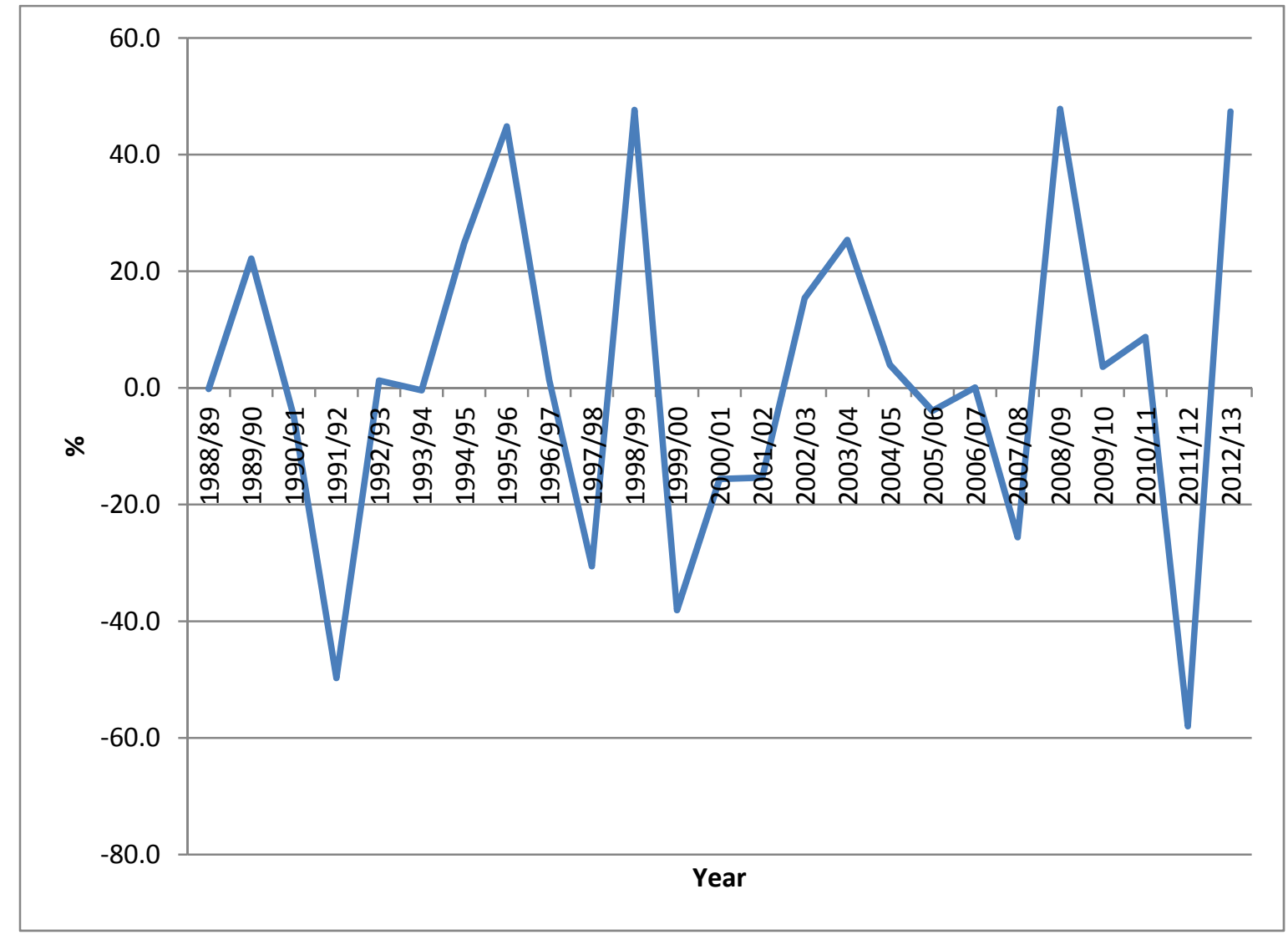

Figure 3. Percentage change in net investment expenditure 
The interesting dimension of Figure 3 is the volatility in the percentage change of net investment expenditure. Nevertheless, this volatility conceals the interesting result of overall growth as reflected by the average annual (real) growth rate of 3.4 percent thereby indicating the expansion of the TCF industry's capital stock. This appears to have been fundamentally prompted by the need to produce the more capital intensive higher niche value added products on a larger scale for the international market in order to offset the domestic market losses emanating from the increased import penetration, particularly the more labour intensive low value added products. The expansion of the capital stock is also likely to have been aimed at displacing labour in a labour intensive industry in order to increase the capital intensity of production (as reflected by Figure 2) and thus provide a significant dampening effect on labour and hence overall costs.

The positive impact of the industry specific assistance measures in the form of the Industry Development Strategy (IDS) and the larger in magnitude Strategic Investment Programme (SIP) on investment expenditure has facilitated the expansion of the capital stock i.e. see the Productivity Commission (PC) Report (PC 2013) for the effectiveness of these measures in stimulating investment expenditure. Moreover, the low interest rate environment since the early 1990s is also likely to have boosted investment expenditure, in this particular instance, by reducing the cost of funds. However, a notable barrier to higher levels of investment expenditure which are needed to expand the capital stock has been the inability of small to medium sized enterprises (SMEs) which dominate the TCF industry to gain access to domestic capital markets, irrespective of their profitability i.e. see (Jayanthakumaran 2001).

\subsection{Research and Development Expenditure}

The Australian TCF industry's response to the pressures of globalisation is also gauged by assessing the growth of research and development $(\mathrm{R} \& \mathrm{D})$ expenditure. This is specifically assessed by calculating the (real) percentage change of R\&D expenditure in the period 1988/89-20110/11 which is highlighted by the following figure. (Note 4)

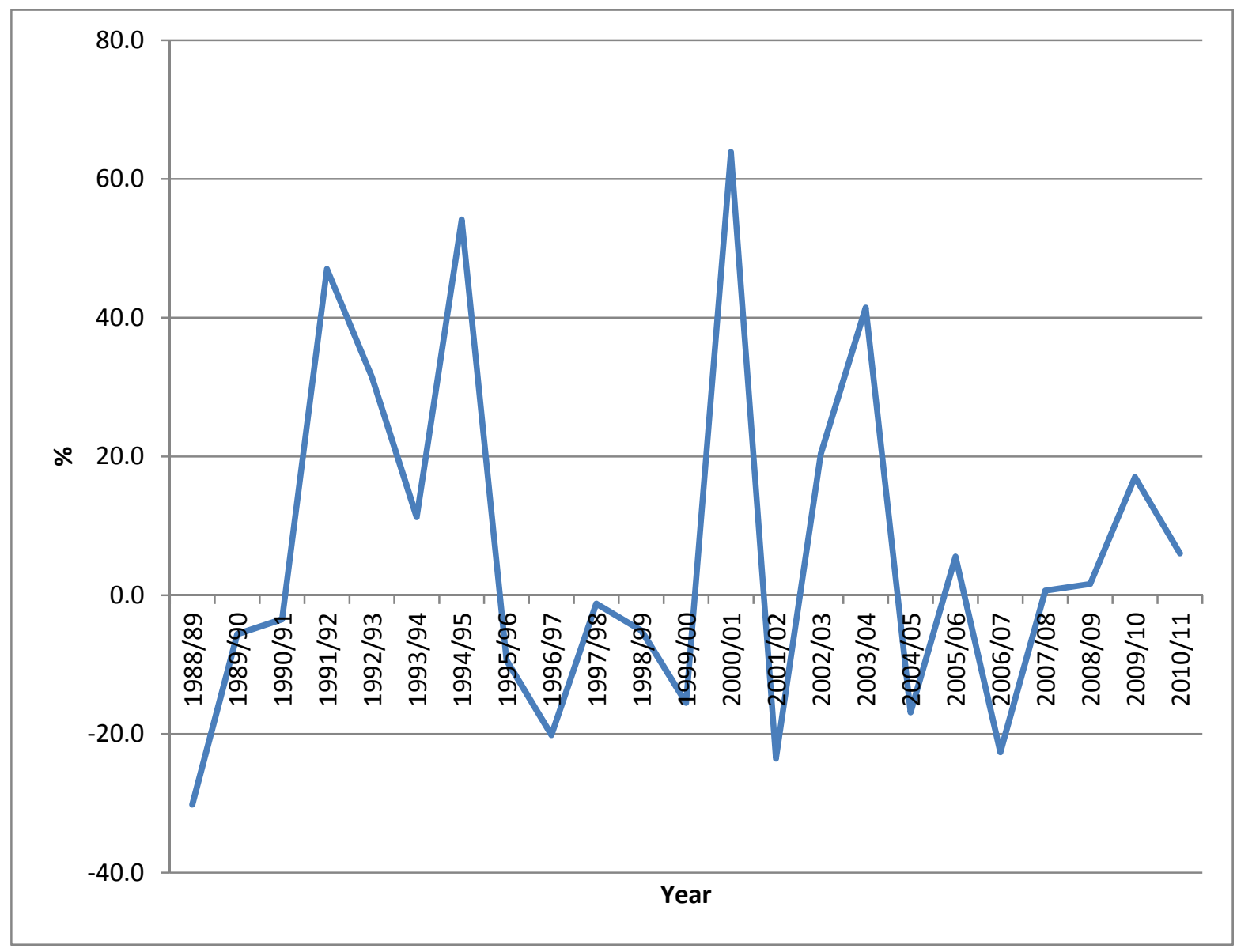

Figure 4. R\&D expenditure 
There are a number of interesting dimensions related to Figure 4. First, the growth rate in R\&D expenditure has been largely positive with a number of large increases. Negative growth has occurred less often and has been of a smaller magnitude compared to the years of positive growth. The slowdown in the growth rate of R\&D expenditure in the more recent period appears to constitute a natural phenomenon after strong growth in the earlier years from a particularly low base. The overall $R \& D$ performance is encapsulated by the average annual growth rate of 6.1 percent in the period 1988/89-2010/11. The strong R\&D performance is likely to fundamentally reflect the trade liberalising heightened import competition prompting firms to intensify their effort to add value to products and improve quality as a means of confronting this challenge see (IC 1997) and (PC 2003). The industry specific assistance measures provided under the IDS and SIP are likely to have facilitated this favourable R \& D response. This assertion is vindicated by the (IC 1997) which reveals the positive effect of the former on R\&D expenditure in the period 1987-1995 and the PC (2003) which highlights the favourable impact of both these programs in stimulating $R \& D$ expenditure. However, it is interesting to note higher $R \& D$ expenditure is likely to have been hampered due to the concentration of this expenditure by the larger more profitable firms with the small to medium sized firms which dominate the TCF industry less able to use this avenue to improve international competitiveness because of their limited capacity to generate profits.

\subsection{Quality Improvements}

The trade liberalisation-induced restructuring of TCF production towards higher value added products has made it easier for firms to specialise in niche areas. This narrower focus facilitates quality improvements as a means of augmenting international competitiveness. Indeed, this is the conclusion reached by the (IC 1997). It is important to emphasise that the improvement in quality is likely to have derived from the more capital intensive nature of production in combination with the more skilled labour force and the stronger $\mathrm{R}$ and $\mathrm{D}$ effort, all of which are traits of high tech production. Interestingly, more capital intensive production entails investment in new capital goods which tend to incorporate superior technology thereby enhancing the ability of firms to produce higher quality TCF products. The Australian TCF industry's experience with quality is consistent with that of other western economies. For example, the Massachusetts Institute of Technology's (MIT) Commission on Industrial Productivity (MIT 1989) notes that quality improvements have been an important avenue via which the TCF industries in these economies have combated the rising import competition of labour intensive low value added TCF goods, principally from developing economies.

\section{The Export Performance of the Australian TCF Industry}

The improvement in the economic fundamentals of the Australian TCF industry as reflected by the higher labour productivity, expansion of the capital stock, higher levels of R\&D expenditure and the improvement in the quality of output have raised the international competitiveness of TCF exports. The extent to which this has occurred is highlighted by gauging movements in export oriented production in the period 1988/89-2012/13 with the assistance of the following figure. (Note 5) 


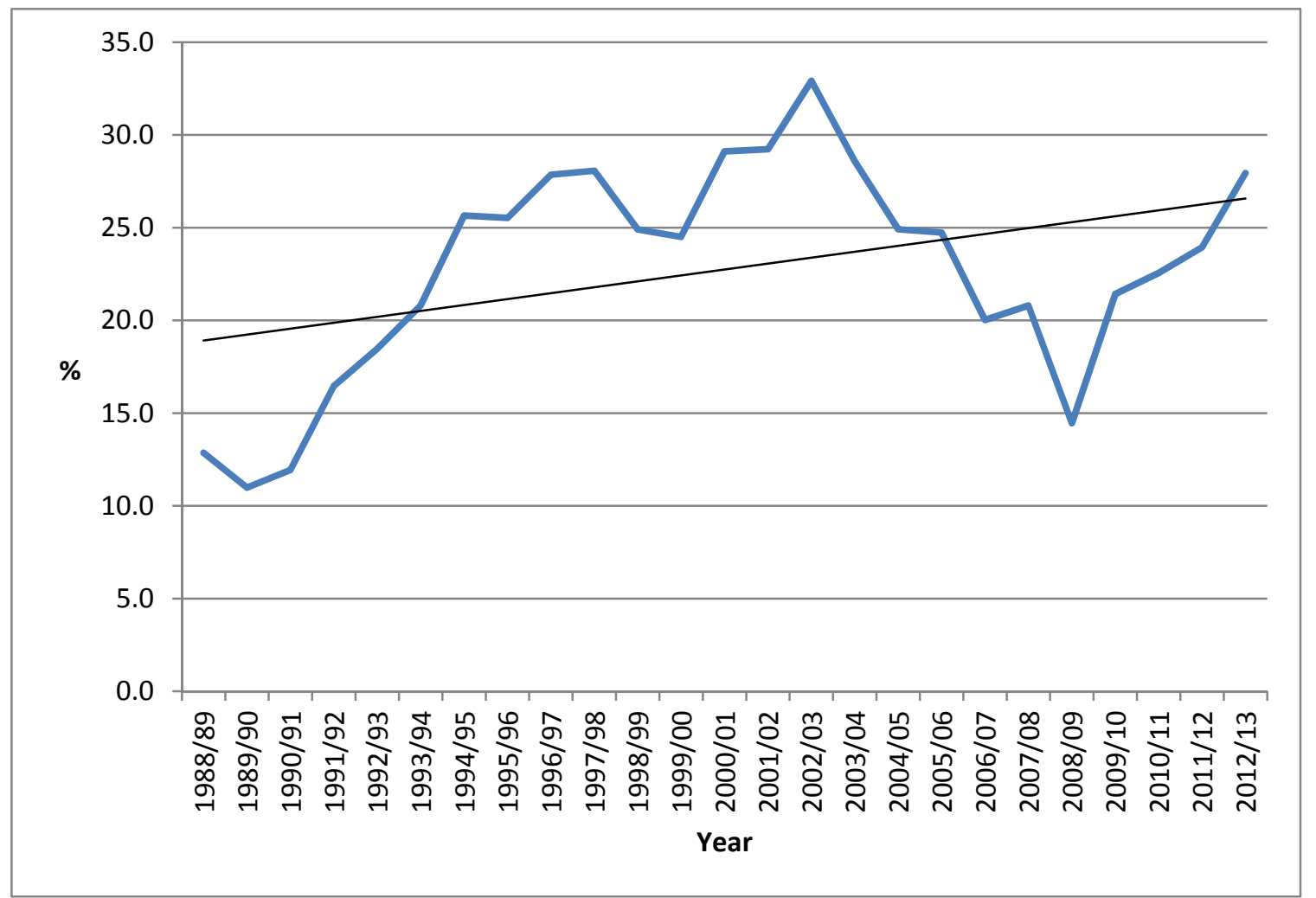

Figure 5. Export oriented production

Figure 5 reveals rising export based production on a trend basis. Of note however is that this trend has been limited and highlights the difficulty experienced by a high wage cost country such as Australia in exporting labour intensive TCF products. Nevertheless, the sharper export focus conceals the interesting phenomenon whereby the restructuring of production from the low to high value added goods has reinforced the long term trend to specialise in the latter products which include textile fibres, yarn and leather products thereby indicating the specific products driving the higher export profile. The increasing dominance of high value added TCF products in the export base in turn is likely to have intensified the use of high tech production techniques to accommodate the higher production of these products. An particularly interesting dimension of high tech production is the enhanced ability to use computer controlled technology and microelectronics to combat costs of production and improve quality in order to augment the export competitiveness of the high value added products The low value added TCF goods such as clothing and footwear which have traditionally constituted a small proportion of TCF exports have been migrating to the developing economies which have a comparative advantage in this area due to their abundance of labour. This transfer of production has been given additional imputes due to the heightened import competition for the low value added products emanating from the pursuit of free trade by the international TCF industry which has led to the abolition of the Multi Fibre Agreement (MFA) where import quotas were progressively eliminated in the period 1995-2005 under the General Agreement on Tariffs and Trade (GATT) sponsored trade negotiations. The Pacific Rim countries have been the primary beneficiaries of this transfer of production i.e. see (Webber and Weller 2001). It is important to highlight that the restructuring of TCF production in Australia has been facilitated by the improvement in the speed and cost of transportation and communications which has made it possible to shift the low value added TCF production to these developing economies. Of note is that specialisation in production of the high quality and high value added TCF products has also been the hallmark of other western market economies in their quest to confront the strong import competition from developing countries i.e. see Cline (1987) for various European countries and Yamawaki, (1989) for Japan. However, as in the case of Australia's experience, this response is also likely to incorporate the effort of TCF producers in western market economies to overcome the competitive disadvantage of a high wage cost structure in a labour intensive industry by intensifying specialisation in production. 
Another important feature of Figure 5 is the fluctuating manner in which export based production has increased. This feature is characterised by two distinct phases. First, there has been a tendency for a marked improvement in the period 1987/88 to the late 1990's which is likely to reflect the greater scope for improvement in the early years after the change in the direction of trade policy. Secondly, there has been a deteriorating trend since 2004/05 which appears to be largely explained by the commodity boom driven appreciation of the exchange rate and domestic demand buoyancy that have combined to discourage exports. Finally, the appreciable improvement in export based production in the years leading to 2003/04 and which reaches a peak in that year appears to constitute the reaction of firms to the expected losses in the domestic market emanating from the resumption of tariff rate reduction in 2005.

The plethora of economy wide microeconomic reforms is also likely to have made a contribution to the sharper export focus of the TCF industry. For example, Forsyth (2000) notes that the deregulation of infrastructure services such as transportation, storage, telecommunications and energy has led to higher productivity in various sub periods from the mid-1980s to the late 1990s, a trend which is likely to have continued in light of the maintenance of a highly competitive environment. This combats the costs of using these infrastructure services as inputs into the production process throughout the economy which includes those of the TCF industry thereby augmenting international competitiveness. Finally, the higher export profile of the Australian TCF industry has also been the product of the generally buoyant international economic conditions prevailing and the liberalisation of the international TCF market which have facilitated export penetration. It should be noted that these two external developments constitute critical complements to domestic policy in achieving this important result. It is critical to emphasise that the sharper export focus of TCF producers has provided a platform for sustainable output and employment growth due to the stronger penetration of the international market thereby ultimately safeguarding the long run viability of the TCF industry.

\section{The Costs of Globalising the Australian TCF Industry}

The sharper export focus of the Australian TCF industry has been underpinned by the more intense specialisation in the production of the high value added products. However, this has been associated with the shedding of low value added products which have migrated to the neighbouring developing economies. The net impact of these opposing forces on output is highlighted in the period 1988/89-2012/13 with the assistance of the following figure.

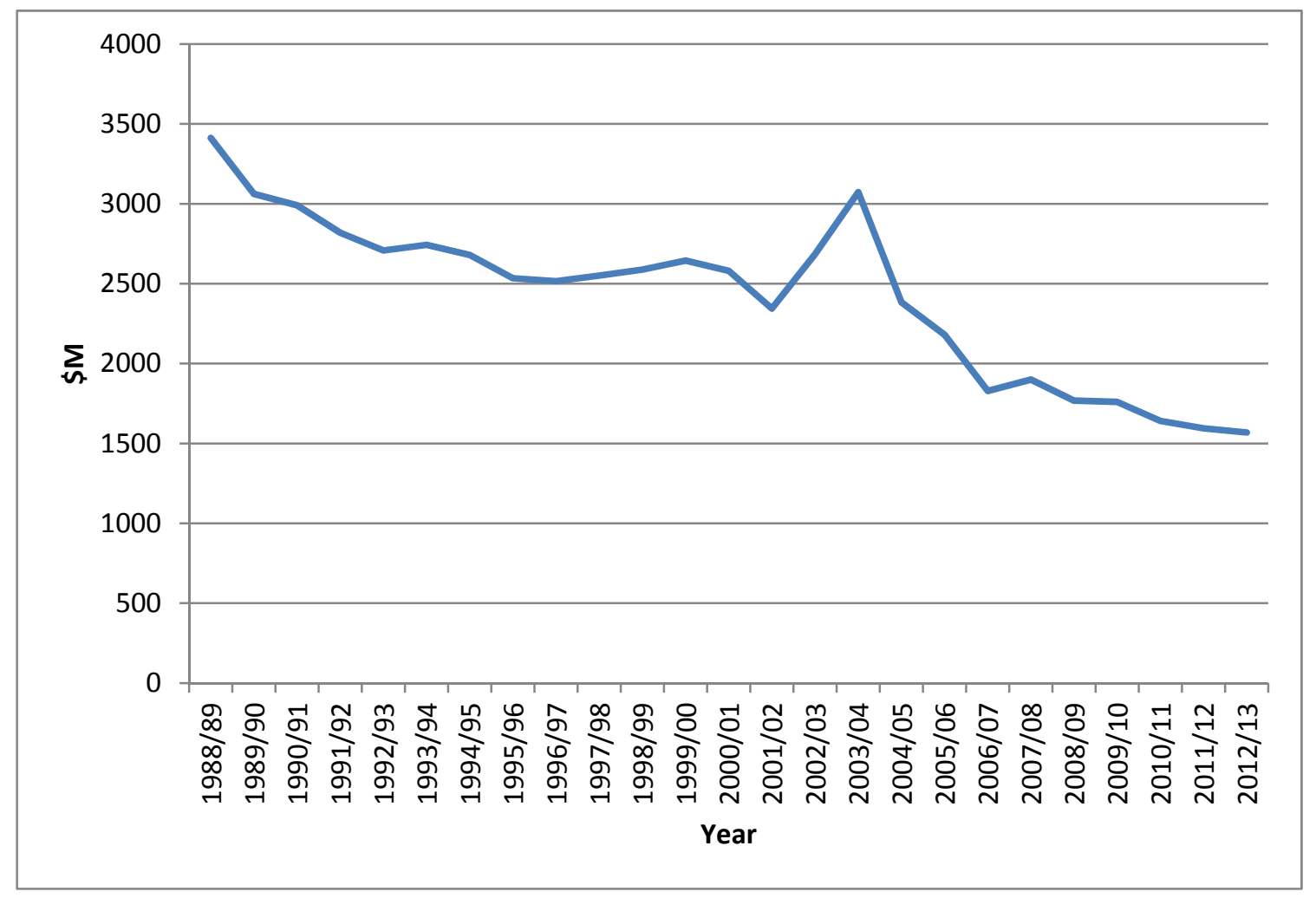

Figure 6. Value of TCF output 
Figure 6 depicts a pronounced contraction in TCF production which equates with an average annual decline of -1.3 percent. It is interesting to note the more acute contraction since 2004/05 which highlights the difficulty experienced by the Australian TCF industry to operate in a particularly low tariff rate environment due to the strong import competition emanating from countries with a comparative advantage in labour intensive production i.e. developing economies. The sharp increase in output in 2003/04 appears to reflect the extraordinary effort made by firms to bolster exports in light of the resumption of tariff rate reductions from 2005 which were expected to lead to further losses in the domestic market.

The contraction of TCF production is likely to have led to employment losses, the magnitude of which is crystalised with the assistance of the following figure.

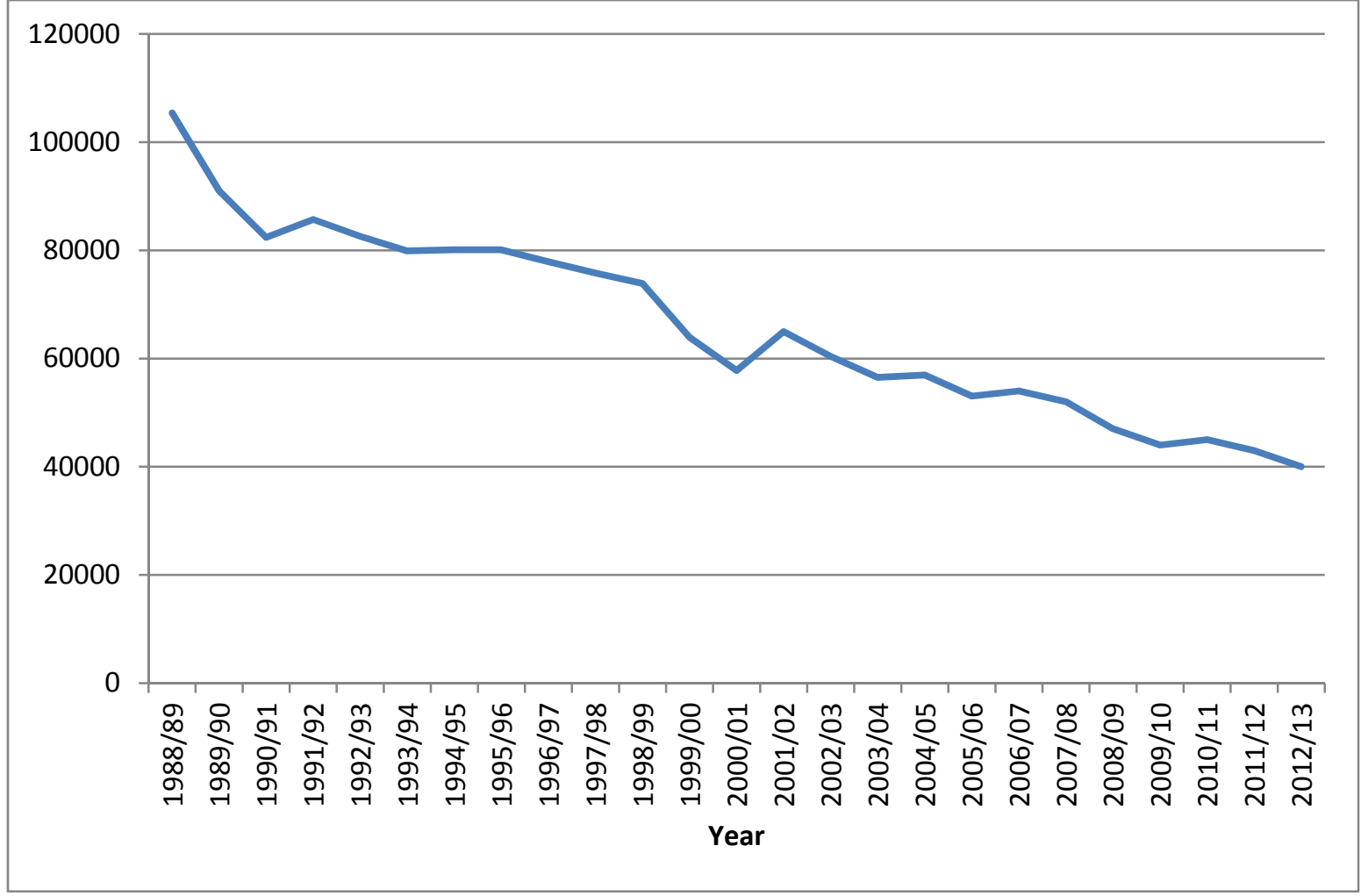

Figure 7. Level of TCF employment

Figure 7 displays an appreciable fall in employment in the period 1988/89-2012/13 which has been of the order of - 1.6 percent on an average annual basis. An interesting dimension of the employment losses has been the concentration among the unskilled males who dominate in production, as revealed by (Weller and Webber 1999). It is also interesting to note the more pronounced decline in employment relative to output which confirms the labour intensive nature of TCF production. The output and employment losses however appear underestimated due to the output and employment losses associated with the loss of outworkers, which the (IC 1997) notes have been difficult to estimate. Nevertheless, they are likely to have been moderate due to the concentration of outworkers in only one segment of the TCF industry i.e. women's apparel and other clothing.

One other notable cost associated with the sharper export focus of the Australian TCF industry is the greater vulnerability of production to the fluctuations of the international business cycle. For example, a prolonged deep international recession will have a commensurate dampening effect on exports and hence output and employment growth due to the closer synchronisation of this industry's business cycle with that of the international economy.

\section{The Impact on Real Wages}

It is important to assess the impact of the employment losses on wages and hence labour costs due to the implications for international competitiveness. This task is pursued by examining movements in real wages per employee in the period 1988/89-2012/13 which are depicted by the following figure. (Note 6) 


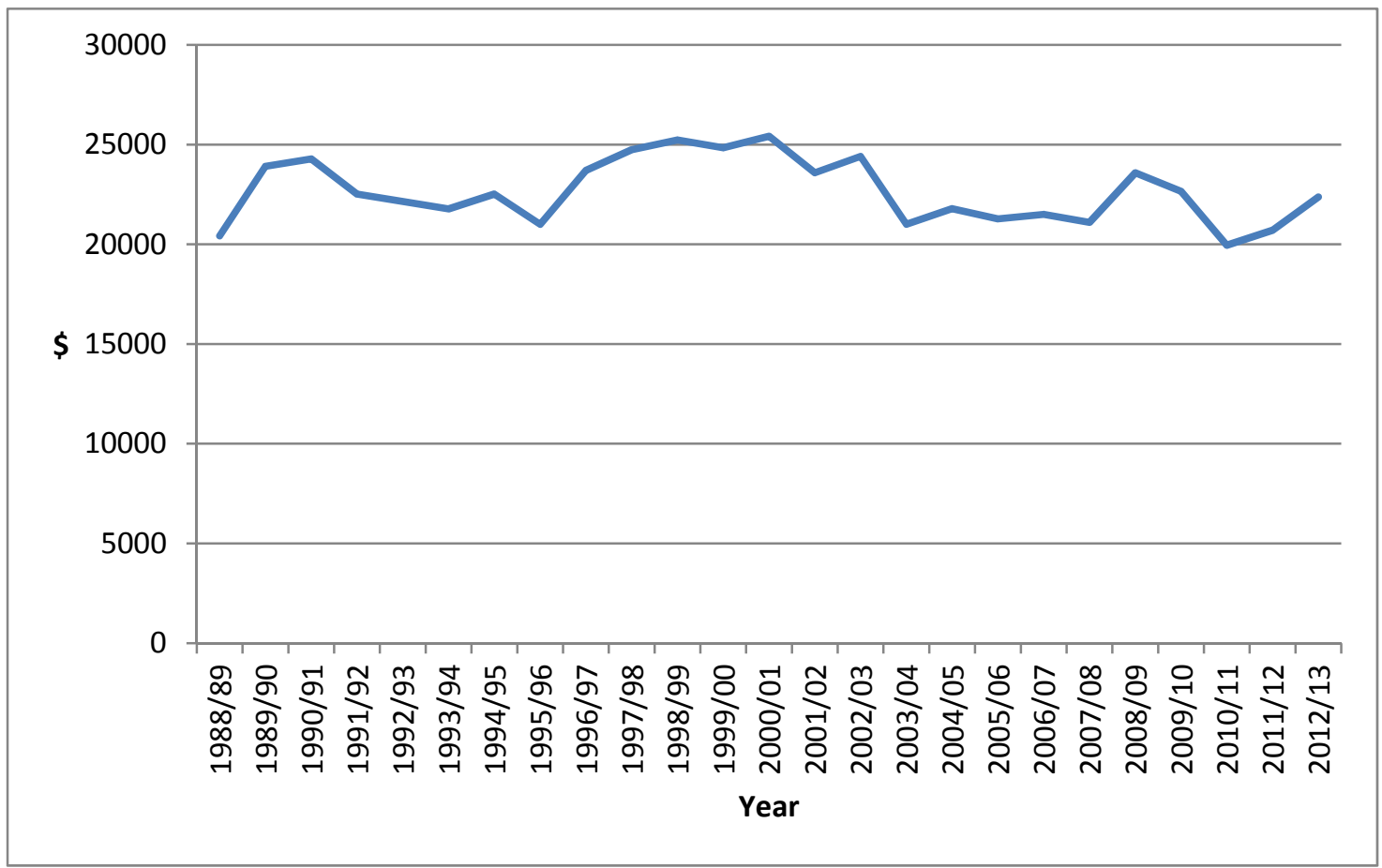

Figure 8. Real wages per employee

The interesting dimension of Figure 8 is the fluctuations in real wages per employee within the range of $\$ 20,000-\$ 25,000$. This result is underpinned by the general tendency for both real wages and employment to fall concurrently at about the same rate. It is important to note that the stagnation in real wages per employee in a labour intensive industry constitutes a major barrier to export competitiveness. This phenomenon is likely to fundamentally reflect the strength of the trade union movement in resisting the downward pressure on wages from the restructuring-induced output and hence employment losses. In the context of the modest improvement in labour productivity growth, this implies only a marginal fall in real unit labour costs thereby maintaining high labour costs and hence competitive difficulties on the international market.

The persistence of a high wage cost structure in a labour intensive industry constitutes a major barrier to TCF exports, to the extent it is likely to have reinforced trade liberalisation in creating a powerful incentive for firms to implement offsetting measures to preserve and promote export competitiveness at a time of increasing import penetration and hence domestic market losses. One such offsetting measure which is likely to have been adopted is the further mechanisation of production which is attested by the rising capital intensity of production (i.e. see Figure 2) in order to conserve the use of labour and hence restrain labour and thus overall costs. However, this is likely to have compounded the employment losses in the process. Employment losses are likely to have been accentuated by the increased use of outworkers, particularly in the women's apparel and other clothing segments of TCF production in order to further combat labour and hence overall costs i.e. see (IC 1997). However, the extent to which this may have occurred is likely to have been mitigated by the introduction of the Federal Trades Awards (1982) which stipulates the need for similar re-numeration and working conditions for employees directly and those indirectly employed by the TCF industry such as outworkers.

The output and employment losses in the Australian TCF industry have economy wide implications in that this is also likely to be the case for other labour intensive high wage cost manufacturing industries. However Australia has a comparative advantage in the production of capital intensive manufacturing goods which implies these industries are likely to be expanding over time. The transition phase whereby resources shift from labour to capital intensive manufacturing industries is therefore likely to involve an increase in unemployment. Consequently, manpower policies will need to be geared towards the education and training of the labour force to cater for the rising production of the capital intensive high valued added manufacturing goods in order to promote employment growth in the long run. A particularly important dimension of a highly educated and trained labour force is the ability to progressively move up the value added chain which will maximise export growth due to stronger international demand. The significance of education and training in helping Australia absorb unemployed labour from the contracting labour intensive industries into the expanding capital intensive industries is highlighted by the empirical 
study of (Weller and Webber 1999) which reveals that the re-training of retrenched labour in the Australian TCF industry made the second most important contribution in improving the employment prospects of both males and females in the period 1993-1997.

The major finding of this paper are that the labour intensive and high wage cost TCF industry in Australia has responded to the challenge of globalisation by restructuring production from the low to high value added products which are internationally more competitive. This has ultimately transformed the Australian TCF industry into a learner and more specialised export focused industry thereby providing a platform for sustainable growth in output and employment, albeit on a smaller scale. However, the sharper export focus has been associated with output and employment losses. These results are likely to be indicative of conditions in other labour intensive high wage cost manufacturing industries in Australia (and indeed other western market economies). These revelations are consistent with the theory of free trade as espoused in section 3 and simultaneously have attempted to make a contribution to the literature of TCF production in Australia, other western market economies and hence on a global scale.

\section{Conclusion and Implications for Economic Policy}

The major policy initiatives in the form of trade liberalisation and the reinforcing industry specific assistance measures have been fundamentally responsible in transforming the Australian TCF industry into a leaner and more specialised export focused industry. This turnaround has been underpinned by restructuring production from the low to high value added products which exhibit a comparative advantage on the international market. The production of these goods has been characterised by the use of more high tech production techniques such as combining a higher skilled labour force with elevated levels of R\&D expenditure and more capital intensive production techniques. An important aspect of high tech production is the enhanced ability to use computer controlled technology and microelectronics which combat costs of production and improves the quality of the goods produced thereby reinforcing export competitiveness. The sharper export focus has been achieved within the context of stable real wages per employee in a labour intensive industry which has augmented trade liberalisation and the reinforcing industry specific assistance measures in spurring firms to intensify their use of high tech production techniques to displace labour and hence restrain labour and thus overall costs. Higher export based production has ultimately provided a platform for sustainable TCF production in Australia in the long run, albeit on a smaller scale. However, this has come at the cost of substantial output and hence employment losses due to the transfer of the low value added TCF products to developing economies which exhibit a comparative advantage in this area.

The output and employment losses in the TCF industry are likely to indicate the costs associated with other labour intensive manufacturing industries operating in a high wage costs country such as Australia. Consequently, manpower policies are required to retrain the unemployed labour emanating from the contracting TCF and other manufacturing labour intensive industries with the appropriate skills to facilitate the expanding production of the capital intensive high value added manufacturing goods upon which Australia has a comparative advantage on the international market. This implies that budgetary policy will need to give preference to expenditure for retraining programs in order to promote employment growth and hence avoid an increase in unemployment in the long run. Finally, it would be interesting to observe whether Australia's experience of labour intensive TCF production in the context of a high wage cost structure and a globalised environment also prevails in other small as well as large western market economies.

\section{References}

Australian Bureau of Statistics (ABS). Manufacturing Industry, Cat. No.8221.0, Canberra.

Australian Bureau of Statistics. Australian Industry, Cat. No.8155.0, Canberra.

Australian Bureau of Statistics. Australian System of National Accounts, Cat. No.5204.0, Canberra.

Australian Bureau of Statistics. Balance of Payments and International Investment Position, Cat. No.5302.0, Canberra.

Australian Bureau of Statistics. Merchandise Exports, Cat. No.5368.0, Canberra.

Australian Bureau of Statistics. Research and Experimental Development Business, Cat. No. 8104.0, Canberra.

Building a Competitive Australia. (1991). AGPS: Canberra.

Cline, W.R. (1987). The Future of World Trade in Textiles \& Apparel. Institute for International Economics, Washington.

Corden, M.W. (1996). Protection and Liberalisation in Australia and Abroad. Australian Economic Review, 2nd Quarter. http://dx.doi.org/10.1111/j.1467-8462.1996.tb00921.x

Dicken, P. (2011). Global Shift: Mapping the Changing Contours of the Global Economy (6 ${ }^{\text {th }}$ ed.). London: Sage Publications. 
Forsyth, P. (2000). Microeconomic Policies and Structural Reform. In Gruen, D. and Shresth, S. (Eds.), The Australian Economy in the 1990s (pp.235-267). Sydney: Reserve Bank of Australia.

Industry Assistance Commission (IAC). (1986). The Textile, Clothing and Footwear Industries, Report No. 386, Vol.1 to 3. Canberra: AGPS.

Industry Commission (IC). (1997). The Textile, Clothing and Footwear Industries, Vols. 1 and 2. Canberra: AGPS.

Industry Commission. (1995). Australian Manufacturing Industry and International Trade Data 1968/69-1992/93. Canberra: AGPS.

International Labour Organisation (ILO). (1996). Globalisation of the Footwear, Textiles and Clothing Industries: Report for Discussion at the Tripartite Meeting on the Globalisation of the Footwear, Textiles and Clothing Industries: Effects on Employment and Working Conditions. Geneva: ILO.

Jayanthakumaran, K. (2001). Trade Policy Reforms and the Textile, Clothing and Footwear Industries in Australia 1992/93-1996/97. Economic Papers, 20, 1-12, http://dx.doi.org/10.1111/j.1759-3441.2001.tb00276.x

Marks, A. (2009). Trade Liberalisation and the Intra Industry Trade Performance of the Textile, Clothing and Footwear and Motor Vehicle Industries: A Comparative Case Study Approach. Economic Papers, 28(4), 323-336., http://dx.doi.org/10.1111/j.1759-3441.2010.00040.x

Marks, A. (2013). The Globalisation of the Australian /Textile, Clothing and Footwear and Motor Industries: Results in Line with Other Western Market Economies. Global Economy Journal, 13, 1-22. http://dx.doi.org/10.1515/gej-2012-0023

Massachusetts Institute of Technology (MIT) Commission on Industrial Productivity. (1989). The U.S. Textile Industry: Challenges and Opportunities. The Working Papers of the MIT Commission on Industrial Productivity. Massachusetts: The MIT Press.

May Economic Statement. (1988). Canberra: AGPS.

Productivity Commission (PC). (2003). Review of TCF Assistance, Report No. 26. Canberra: AGPS).

United Nations (UN). (2008, 09, 10 and 11). Industrial Commodity Statistics Yearbook, 2. New York.

Webber, M., \& Weller, S. (2001). Trade and Inequality: Australia's Textile, Clothing and Footwear Industry. Journal of Economic Geography, 1, 381-403. http://dx.doi.org/10.1093/jeg/1.4.381

Weller, S., \& Webber, M. (1999). Re-employment after Retrenchment: Evidence from the TCF Industry. Australian Economic Review, 32, 105-129. http://dx.doi.org/10.1111/1467-8462.00099

Yamawaki, H. (1989). International Competition \& Domestic Adjustments: The Case of the Japanese Textile Industry. Research School of Pacific Studies, Canberra, ANU.

\section{Notes}

Note 1. Data on multi factor, capital or labour productivity are not available according to the Australian Bureau of Statistics (ABS). Consequently, labour productivity has been proxied by the real value of output (at 1989/90 prices) divided by the number of employees.

Note 2. These studies also use output per worker to reach this result.

Note 3. The rising capital intensity of TCF production is gauged by the level of net investment as a proportion of output in real (1989/90 prices) terms. This trend is consistent with the (IC 1997) which provides data on an index of capital intensity in production for the manufacturing sector and its eight 2 digit Australia and New Zealand Industrial Classification (ANZIC) subdivisions, which includes the TCF industry in the period 1968/69-1994/95. The data reveals this index to have risen in this industry from 75 to 100 during this period.

Note 4. The real percentage change in R\&D expenditure has been calculated on the basis of deflating the nominal value of R\&D expenditure by the GDP deflator (at 1989/90 prices). It is based on the latest available data (September 2012).

Note 5. Export oriented production is defined as exports as a proportion of turnover in real (1989/90) prices. The interesting feature of this trend is the growth in exports within the context of a contraction in turnover. Export oriented production is different to domestic oriented production which constitutes production based upon domestic demand.

Note 6. Real wages per employee is calculated as wages and salaries paid in the TCF industry deflated by the GDP deflator (in 1989/90 prices) divided by the level of employment in this industry. 